\title{
Studying the Interrelationship amongst the Success Factors for Implementation of ERP Software amongst Educational SMEs in Developing Countries
}

\author{
P. C. Jha \\ Department of Operational \\ Research, Faculty of Mathematical \\ Sciences, University of Delhi \\ Delhi, India
}

\author{
Remica Aggarwal \\ School of Business, University of \\ Petroleum \& Energy Studies, \\ Dehradun, India
}

\author{
P. K. Kapur \\ Amity Center of Interdisciplinary \\ Research, \\ Amity University, Noida, India
}

\begin{abstract}
Indian education sector is a mix of government operated and privately operated institutions as well as other education service providers such as coaching institutes and professional training centers. Now days, this sector is making use of ERP system which is a computer based application used to operate external and internal resources, including materials, tangible assets, human and financial resources together with covering all the features and processes of an institution /enterprise . However the successful implementation of ERP in educational sector and that too in developing countries is not that easy. Present research discusses various success factors for the successful implementation of ERP in educational sector in developing countries. Further, it studies the interrelationship amongst them using ISM methodology. This paper do not consider the case of higher educational institutions in this study .
\end{abstract}

\section{Keywords}

ISM methodology; Enterprise resource planning ; Information technology ; education sector ; developing countries

\section{INTRODUCTION}

The education sector in India has witnessed a paradigm shift in recent times. Once operated primarily as a philanthropic or a nation building activity, it has since transformed into a 'sector in its own right. This sector is a mix of governmentoperated \& privately operated educational institutions and allied education products \& services providers. India has a significant young population which calls for a robust education sector to harness potential for human capital. Therefore due to an increase in competition coupled with the increasing need to provide quality education and generating positive learning outcomes, the Indian education sector is slowly but steadily moving on the reforms track. The sector is highly influenced by various government schemes and policies launched primarily to improve the quality of education and the planned expenditure through several schemes.

Recently the focus of educational institutions has been on use of financial and resource planning software. Although they are quite common with business units which uses them for maintaining their financial accounts, filing of taxes and updating of balance sheets. They are quite new in educational SMEs which are using them for account handling and enterprise resource planning. Choosing a good financial and accounting software is a necessity of these organisations, reasons being many. One of them is the unsystematic way of bookkeeping their financial records and cash flow. There are different ways to manage financials, such as doing it manually (writing down the transactions in a book), Electronic (via spreadsheet) or an accounting software.

With the onset of GST in India, the businesses that comply the rules of GST is made to operate under various regulations. Selecting a good GST software is crucial for the business and a good accounting software can help you save time and money lost in complying with the GST law. These software could be offline or online. Offline softwares are helpful and an expert in handling bulk transactions. With online softwares synchronising the data across the office on different computer system is easy and most of the things can be saved on an online server as and when you entered the transaction. Selection of an appropriate software requires consideration of factors such as a user friendly interface and just and appropriate budget. Most common features that customers look at in the GST software is that it should be able to customise the look and feel according to the business; should be able to categorise the expenses into different categories and should be able to manage inventory, inward-outward stock movements, and wastage. In addition, it should support for multi- currency transactions and able to manage employees and office payrolls . Common GST softwares are profit books (online accounting software) ; tally ERP 9 (offline accounting software ); Zoho books ( cloud based accounting software ); Clear tax ( IT return filing software) and Intuit quick books (online accounting software for international market ). So, if a customer or organisation want an offline accounting software and have an accountant to operate it, they may make use of Tally. If an easy to use GST software is to be used, organizations can adopt ProfitBooks. It is a complete accounting software which fully complies with GST law. Its designed in India and or Indian businesses. It has the most simple interface among all the softwares available in the market. Major benefits of ERP include its complete integration with all the business processes, reduction in the volume of data entry, upgradability of the technology, portability to other systems, adaptability, and applying best practices [1].

This research work focuses on ERP software and various success factors and barriers associated with it. Paper is organised as follows : Section 2 deals with literature review . Section 3 deals with ISM methodology and section 4 explains the case example along with the use of ISM to the case . Managerial implications have been discussed in section 5 . 


\section{LITERATURE REVIEW ON ERP SOFTWARE AND FACTORS FOR ITS SUCCESSFUL IMPLEMENTATION}

Modern organizations are making significant investments in complex information systems such as the enterprise resource planning (ERP) systems. The ERP architecture is three tier architecture , allowing multiple users to work simultaneously from multiple locations on a single database, where an application server provides data for clients at an interface between client and database server. It deals with centralized database to create a distributed environment, bridges the information gap across the organization. Major features include manging HR and payroll ; invoicing and billing ; supplier and purchase order management ; taxation management ; financial and inventory management and supplier and purchase order management. Despite their avowed benefits, more than two thirds of ERP system projects result in failure [2]. The quite obvious reason being that Indian organizations have been exposed to advanced use of IT that are made possible through joint ventures and technology transfer initiatives. Thus, it is pertinent to understand the influence of the various factors influencing the acceptance of ERP in the Indian context [3] . Various critical success factors including the impact of enterprise resource planning [[4], [5] , [6]] ; effect of organisational support [7] ; impact of business process on ERP system effectiveness [9)] ; user satisfaction [1] ; effect of computer efficacy [9] ; cultural factors [10]; organisational factors [11]; usage of ERP [12] ; cloud ERP adoption amongst SMEs [13] . Similarly, among the implementation of ERP at international level [14] discusses the various critical success factors for ERP implementation in Belgian SMEs .

Based on the review of extant literature, following are the listed factors for the successful implementation of ERP particularly in developing countries like India .

\subsection{Process adoption by employees or employees convenience with using ERP (PAE)}

At present not much research has been done to study the factors that show the impacts of process change of complex technology solutions like the ERP on employees [15]. This is quite necessary now-days to know how different factors have influenced information system (IS) deployment in Indian firms[16].

\subsection{Appropriate individual performance \\ (AIP)}

With the rapid growth in use of computing, academicians and practitioners have recognized that IT success can be measured by its impact on an individual's work [17]. Users would adopt an ERP system if they perceived ERP would assist them to attain desired performance outcomes. Some of these studies that have used individual performance in their study have stated positive relationships between IS and performance [15].

\subsection{Appropriate computer self-efficacy}

\section{(ACSE)}

Self-efficacy is a measure of a user's confidence in his/her ability to use a technology[18]. It is the people's judgements of their capabilities to organise and execute courses of action required to attain designated types of performances [19]. Computer self-efficacy was found to play an important role in explaining usage intention through perceived usefulness $[20,21]$.

\subsection{Appropriate organizational support ( AOS)}

In an ERP system environment, top management and organisational support is quite important to keep the employees motivated to improve their performance through usage of the new system [22,23].

\subsection{Appropriate training and education (ATE)}

Enterprise resource planning systems are extremely complex and demand rigorous training. Training and education will reduce employees' anxiety and stress about the use of the ERP system and provide better understanding about the benefits of the system for their tasks [23].

\subsection{Good investment in e- business technology (IBT)}

Considering that developing countries usually have an uncertain, turbulent and complex business environment [24], it is expected that external influences have significant effects on the adoption of e-business. In investigating the impact of industry pressure on e-business adoption across the ERPenabled firms, it is found that industry pressure inhibits ebusiness adoption in ERP-enabled firms. Therefore a good investment in e- business technology can set a company's standard

\subsection{Government resource and regulatory support (GRRS)}

As expected, government resource support and government regulatory support are found to be statistically significant and positive predictors of e-business adoption in the full sample [24] .

\subsection{Medium Technological complexity (MTC)}

Enterprise resource planning systems, similar to other management information systems, are often perceived as very complex and difficult to implement [25]. This limits the amount of knowledge that users can absorb before actual usage [26]. Higher complexity results in higher mental workload and stress [27] and therefore it is negatively related to individual attitude towards the system [11]. Hence, it is suggested that the complexity should neither be too high nor be too low.

\subsection{Technological compatibility (TC)}

As indicated by [5], ERP is significantly described by competitive pressure and systems compatibility. As a result technological compatibility is considered as one of the technological characteristics that affects the usage of ERP [28].

\subsection{Panoptic empowerment (PE)}

The panoptic empowerment effect is an early nineteenth century design for prisons developed by Bentham. This effect was used to induce in the prisoners a state of conscious and permanent visibility that assures the automatic functioning of power [29]. An ERP works in a similar manner and records all user actions in real-time and also stored it for later observation [30]. This ensures greater visibility of information and empowers workers to do their work more efficiently and effectively [31]. 


\section{INTERPRETIVE STRUCTURAL MODELLING METHODOLOGY}

Interpretive Structural Modeling or ISM first proposed by Warfield [32] is a computer assisted learning process that enables the researcher to develop a map of the complex relationships between the many elements involved in a complex situation. In this technique a set of unique interrelated variables are structured in the form of a hierarchy graph called the diagraph. Its steps are as follows: Firstly, identify the relevant elements and establish a contextual relationship amongst them. Thereafter, develop a structural self-interaction matrix (SSIM) using V, A, X \& O where the symbols have the following meanings i.e. $\mathrm{V}$ for the relation from $i$ to $j$ but not in both directions; $A$ for the relation from $j$ to $\mathrm{i}$ but not in both directions; $\mathrm{X}$ for both direction relations from $i$ to $j$ and $j$ to $i$; and $\mathrm{O}$ if the relation between the variables does not appear valid. Using SSIM, initial reachability matrix can be formed which has all values in binary form. A final reachability matrix is formed after removing transitivity from initial reachability matrix. From the final reachability matrix, the reachability set and antecedent set for each criterion and for each element is found [32]. The element for which the reachability and intersection sets are the same is the top-level element. At every iteration a top level element is identified which is removed in the next iteration. After all the elements have been identified at different level of hierarchy, a Mic-Mac analysis (based on the driving power and dependence power) and a diagraph can be formed.

\section{DEVELOPMENT OF ISM MODEL}

This section develops the ISM model for interrelationship amongst the success factors for implementation of GST softwares amongst educational SMEs in developing countries.

\subsection{Construction of Structural Self - Interaction Matrix (SSIM)}

This matrix gives the pair-wise relationship between two variables i.e. $i$ and $j$ based on VAXO. SSIM has been presented below in Fig 1.

\subsection{Construction of Initial Reachability Matrix and final reachability matrix}

The SSIM has been converted in to a binary matrix called the initial reachability matrix shown in fig. 2 by substituting V, A, $\mathrm{X}, \mathrm{O}$ by 1 or 0 as per the case. After incorporating the transitivity, the final reachability matrix is shown below in the Fig 3.

Fig 1: SSIM matrix for pair wise relationship amongst barriers

\begin{tabular}{|c|c|c|c|c|c|c|c|c|c|c|c|}
\hline $\begin{array}{c}\text { Barrier } \\
\mathrm{s}\end{array}$ & & 1 & 2 & 3 & 4 & 5 & 6 & 7 & 8 & 9 & 10 \\
\hline & & PAE & AIP & ACSE & AOS & ATE & IBT & GRRS & MTC & TC & PE \\
\hline 1. & PAE & & V & A & A & A & A & A & A & A & A \\
\hline 2. & AIP & & & A & A & A & A & A & A & A & A \\
\hline 3. & ACSE & & & & A & A & A & A & A & A & A \\
\hline 4. & AOS & & & & & V & V & A & V & X & V \\
\hline 5. & ATE & & & & & & A & A & A & A & A \\
\hline 6. & IBT & & & & & & & A & X & X & V \\
\hline 7. & GRRS & & & & & & & & V & V & V \\
\hline 8. & MTC & & & & & & & & A & V \\
\hline 9. & TC & & & & & & & & & & V \\
\hline 10. & PE & & & & & & & & & \\
\hline
\end{tabular}

Fig 2: Initial reachability matrix

\begin{tabular}{|c|c|c|c|c|c|c|c|c|c|c|c|}
\hline $\begin{array}{c}\text { Barrier } \\
s\end{array}$ & & 1 & 2 & 3 & 4 & 5 & 6 & 7 & 8 & 9 & 10 \\
\hline & & PAE & AIP & ACSE & AOS & ATE & IBT & GRRS & MTC & TC & PE \\
\hline 1. & PAE & 1 & 1 & 0 & 0 & 0 & 0 & 0 & 0 & 0 & 0 \\
\hline 2. & AIP & 0 & 1 & 0 & 0 & 0 & 0 & 0 & 0 & 0 & 0 \\
\hline 3. & ACSE & 1 & 1 & 1 & 0 & 0 & 0 & 0 & 0 & 0 & 0 \\
\hline 4. & AOS & 1 & 1 & 1 & 1 & 1 & 1 & 0 & 1 & 1 & 1 \\
\hline 5. & ATE & 1 & 1 & 1 & 0 & 1 & 0 & 0 & 0 & 0 & 0 \\
\hline 6. & IBT & 1 & 1 & 1 & 0 & 1 & 1 & 0 & 1 & 1 & 1 \\
\hline 7. & GRRS & 1 & 1 & 1 & 1 & 1 & 1 & 1 & 1 & 1 & 1 \\
\hline 8. & MTC & 1 & 1 & 1 & 0 & 1 & 1 & 0 & 1 & 0 & 1 \\
\hline 9. & TC & 1 & 1 & 1 & 1 & 1 & 1 & 0 & 1 & 1 & 1 \\
\hline 10. & PE & 1 & 1 & 1 & 0 & 0 & 1 & 0 & 1 & 0 & 1 \\
\hline
\end{tabular}


Fig 3 : Final reachability matrix

\begin{tabular}{|c|c|c|c|c|c|c|c|c|c|c|c|c|}
\hline $\begin{array}{c}\text { Barrier } \\
\text { s }\end{array}$ & & 1 & 2 & 3 & 4 & 5 & 6 & 7 & 8 & 9 & 10 & D.P \\
\hline & & PAE & AIP & ACSE & AOS & ATE & IBT & GRRS & MTC & TC & PE & \\
\hline 1. & PAE & 1 & 1 & 0 & 0 & 0 & 0 & 0 & 0 & 0 & 0 & 2 \\
\hline 2. & AIP & 0 & 1 & 0 & 0 & 0 & 0 & 0 & 0 & 0 & 0 & 1 \\
\hline 3. & ACSE & 1 & 1 & 1 & 0 & 0 & 0 & 0 & 0 & 0 & 0 & 3 \\
\hline 4. & AOS & 1 & 1 & 1 & 1 & 1 & 1 & 0 & 1 & 1 & 1 & 9 \\
\hline 5. & ATE & 1 & 1 & 1 & 0 & 1 & 0 & 0 & 0 & 0 & 0 & 4 \\
\hline 6. & IBT & 1 & 1 & 1 & 0 & 1 & 1 & 0 & 1 & 1 & 1 & 8 \\
\hline 7. & GRRS & 1 & 1 & 1 & 1 & 1 & 1 & 1 & 1 & 1 & 1 & 10 \\
\hline 8. & MTC & 1 & 1 & 1 & 0 & 1 & 1 & 0 & 1 & 1 & 1 & 8 \\
\hline 9. & TC & 1 & 1 & 1 & 1 & 1 & 1 & 0 & 1 & 1 & 1 & 9 \\
\hline 10. & PE & 1 & 1 & 1 & 0 & 1 & 1 & 0 & 1 & 1 & 1 & 8 \\
\hline & De.P & 9 & 10 & 8 & 3 & 7 & 6 & 1 & 6 & 6 & 6 & \\
\hline
\end{tabular}

D.P : Driving power ; De.P : dependence power

\subsection{Level Partition}

From the final reachability matrix, reachability and final antecedent set for each factor are found. The element for which the reachability and intersection sets are same are the top-level element in the ISM hierarchy. After the identification of top level element, it is separated out from the other elements and the process continues for next level of elements. Reachability set, antecedent set, intersection set along with different level for elements have been shown below in table $\mathrm{V}$ to table XI.

Table 3 : Iteration I

\begin{tabular}{|c|c|c|c|c|}
\hline $\begin{array}{l}\text { S.N } \\
\text { o. }\end{array}$ & $\begin{array}{c}\text { Reachability } \\
\text { set }\end{array}$ & $\begin{array}{c}\text { Antecedent } \\
\text { set }\end{array}$ & $\begin{array}{c}\text { Intersec } \\
\text { tion set }\end{array}$ & $\begin{array}{c}\text { Iteratio } \\
\text { n/ } \\
\text { Levels }\end{array}$ \\
\hline 1 & 2 & $\begin{array}{c}1,2,3,4,5,6,7,8,9 \\
10\end{array}$ & 2 & \\
\hline 2 & 1,2 & $\begin{array}{c}1,3,4,5,6,7,8,9 \\
10\end{array}$ & 1 & \\
\hline 3 & $1,2,3$ & $\begin{array}{c}3,4,5,6,7,8,9 \\
10\end{array}$ & 3 & I \\
\hline 4 & $1,2,3,5$ & $4,5,6,7,8,9,10$ & 5 & \\
\hline 5 & $\begin{array}{c}1,2,3,5,6,8,9 \\
10\end{array}$ & $4,6,7,8,9,10$ & $6,8,9,10$ & \\
\hline 6 & $\begin{array}{c}1,2,3,4,5,6,8 \\
9,10\end{array}$ & $4,7,9$ & 4 & \\
\hline 7 & $\begin{array}{c}1,2,3,4,5,6,7 \\
8,9,10\end{array}$ & 7 & 7 & \\
\hline
\end{tabular}

Table 4 : Iteration II

\begin{tabular}{|c|c|c|c|c|}
\hline S.No. & $\begin{array}{l}\text { Reachabili } \\
\text { ty set }\end{array}$ & Antecedent set & $\begin{array}{c}\text { Intersection } \\
\text { set }\end{array}$ & $\begin{array}{l}\text { Iterati } \\
\text { on }\end{array}$ \\
\hline 2 & 1 & $\begin{array}{c}1,3,4,5,6,7,8,9 \\
10\end{array}$ & 1 & \\
\hline 3 & 1,3 & $3,4,5,6,7,8,9,10$ & 3 & \\
\hline 4 & $1,3,5$ & $4,5,6,7,8,9,10$ & 5 & \\
\hline 5 & $\begin{array}{c}1,3,5,6,8,9, \\
10\end{array}$ & $4,6,7,8,9,10$ & $6,8,9,10$ & \\
\hline 6 & $\begin{array}{c}1,3,4,5,6,8, \\
9,10\end{array}$ & $4,7,9$ & 4 & \\
\hline 7 & $\begin{array}{c}1,3,4,5,6,7, \\
8,9,10\end{array}$ & 7 & 7 & II \\
\hline
\end{tabular}

Table 5 : Iteration III

\begin{tabular}{|c|c|c|c|c|}
\hline S.No. & $\begin{array}{c}\text { Reachability } \\
\text { set }\end{array}$ & $\begin{array}{c}\text { Antecedent } \\
\text { set }\end{array}$ & $\begin{array}{c}\text { Intersection } \\
\text { set }\end{array}$ & $\begin{array}{c}\text { Iterati } \\
\text { on }\end{array}$ \\
\hline 3 & $\mathbf{3}$ & $\begin{array}{c}3,4,5,6,7,8,9,1 \\
0\end{array}$ & 3 & \\
\hline 4 & 3,5 & $4,5,6,7,8,9,10$ & 5 & \multirow{2}{*}{ III } \\
\cline { 1 - 4 } 5 & $3,5,6,8,9,10$ & $4,6,7,8,9,10$ & $6,8,9,10$ & \\
\hline 6 & $3,4,5,6,8,9,10$ & $4,7,9$ & 4 & \\
\hline 7 & $\begin{array}{c}3,4,5,6,7,8,9, \\
10\end{array}$ & 7 & 7 & \\
\end{tabular}


Table 6 : Iteration IV

\begin{tabular}{|c|c|c|c|c|}
\hline $\begin{array}{c}\text { S.N } \\
\text { o. }\end{array}$ & $\begin{array}{c}\text { Reachabilit } \\
\text { y set }\end{array}$ & $\begin{array}{c}\text { Antecedent } \\
\text { set }\end{array}$ & $\begin{array}{c}\text { Intersecti } \\
\text { on set }\end{array}$ & $\begin{array}{c}\text { Iteratio } \\
\mathbf{n} / \\
\text { Levels }\end{array}$ \\
\hline 4 & $\mathbf{5}$ & $4,5,6,7,8,9,10$ & 5 & \multirow{2}{*}{ IV } \\
\cline { 1 - 4 } 5 & $5,6,8,9,10$ & $4,6,7,8,9,10$ & $6,8,9,10$ & \multirow{2}{*}{} \\
\cline { 1 - 4 } 6 & $4,5,6,8,9,10$ & $4,7,9$ & 4 & \\
\hline
\end{tabular}

Table 7 : Iteration $\mathrm{V}$

\begin{tabular}{|c|c|c|c|c|}
\hline $\begin{array}{c}\text { Sr. } \\
\text { No. }\end{array}$ & $\begin{array}{c}\text { Reachability } \\
\text { set }\end{array}$ & $\begin{array}{c}\text { Antecedent } \\
\text { set }\end{array}$ & $\begin{array}{c}\text { Intersection } \\
\text { set }\end{array}$ & $\begin{array}{c}\text { Itera } \\
\text { tion }\end{array}$ \\
\hline 5 & $\mathbf{6 , 8 , 9 , 1 0}$ & $4,6,7,8,9,10$ & $6,8,9,10$ & \multirow{2}{*}{$\mathbf{V}$} \\
\cline { 1 - 4 } 6 & $4,6,8,9,10$ & $4,7,9$ & 4 & \\
\hline 7 & $4,6,7,8,9,10$ & 7 & 7 & \\
\hline
\end{tabular}

Table 8 : Iteration VI

\begin{tabular}{|c|c|c|c|c|}
\hline $\begin{array}{c}\text { Sr. } \\
\text { No. }\end{array}$ & $\begin{array}{c}\text { Reachability } \\
\text { set }\end{array}$ & Antecedent set & $\begin{array}{c}\text { Intersection } \\
\text { set }\end{array}$ & $\begin{array}{c}\text { Itera } \\
\text { tion }\end{array}$ \\
\hline 6 & $\mathbf{4}$ & $4,7,9$ & 4 & \\
\hline 7 & 4,7 & 7 & 7 & VI \\
\hline
\end{tabular}

Table 9 : Iteration VII

\begin{tabular}{|c|c|c|c|c|}
\hline $\begin{array}{c}\text { Sr. } \\
\text { No. }\end{array}$ & $\begin{array}{c}\text { Reachability } \\
\text { set }\end{array}$ & $\begin{array}{c}\text { Antecedent } \\
\text { set }\end{array}$ & $\begin{array}{c}\text { Intersection } \\
\text { set }\end{array}$ & $\begin{array}{c}\text { Itera } \\
\text { tion }\end{array}$ \\
\hline 7 & 7 & 7 & 7 & VII \\
\hline
\end{tabular}

\subsection{Classification of factors}

The critical success factors described earlier are classified in to four clusters viz. autonomous factor, dependent factors, linkage factors and independent factors (mentioned in Table XIII below). Fig. 4 below shows the driving power and dominance diagram.

Table XI : Driving Power \& Dominance Diagram

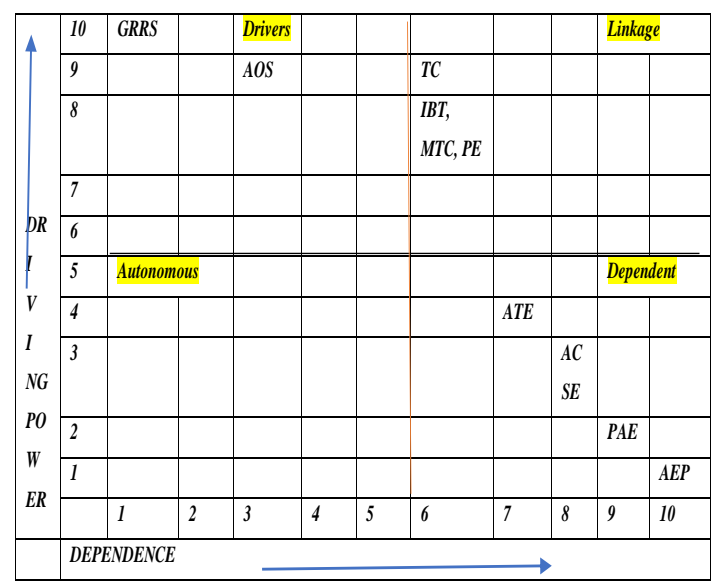

Fig . 4: Driving power and dependence diagram

\subsection{ISM model}

An ISM model is developed ( as shown in fig. 5 below ) after arranging the elements as per their interaction or dependence relationships.

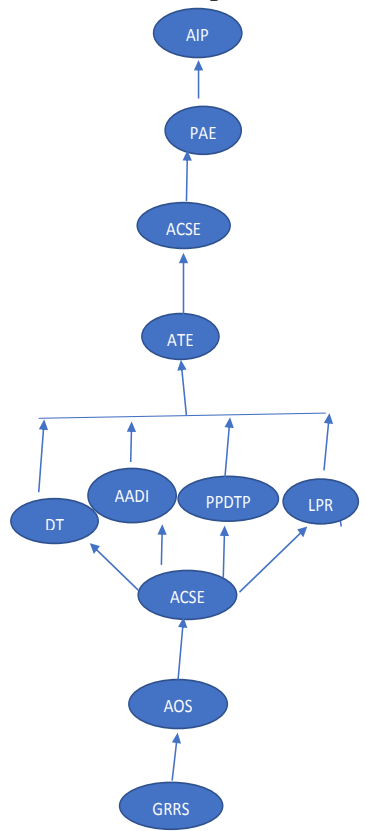

Fig. Diagraph for success factors for implementation of GST softwares amongst educationa SMEs in developing countries

Fig 5: ISM diagraph

\section{MANAGERIAL IMPLICATIONS AND CONCLUSIONS}

Enterprise resource planning systems are different from other innovations of IT because of the socio-technical challenges due to the complexity involved in the implementation process and the different types of end users. Following section describes some of the managerial implications of using ERP . This research has implications for managers as well as organizations. The findings of this study provide insights for managers to efficiently manage the adoption of the ERP system across the organization.

- Enterprise resource planning systems are extensive software systems that integrate a number of business processes, such as manufacturing, supply chain, sales, finance, human resources, budgeting, and customer service activities [33]. They result in enormous investments in software and in package customization[14]. Hence it becomes an utmost duty of the manager to take the appropriate decision while choosing an ERP software. Present study uses various success factors which can be discussed as per organisation needs while taking the decision.

- Successful implementation of ERP requires substantial changes in processes and other social dimensions in order to improve productivity and gain competitive advantage [34], [35].

- It often becomes important for managers to make substantial changes in organizational structure and ways of working as well in order to gain maximum benefits from ERP implementation in their organization [6]. 
- Further, implementation of ERP systems in developing countries is faced with more difficulties than those faced by industrialized countries [25]. This suggests that information technology and management practices need to be modified for different cultural contexts.

- The present study tries to identify the impact of ERP implementation on the individual's panoptic empowerment and individual performance. Managers should have the goal of not just making use of the system but to make employees satisfied with using the system, to improve their performance, and also to empower them to make decisions.

- Further research can be done through a longitudinal approach for the study. This will help to understand how the factors vary at different stages in the implementation process of ERP.

\section{ACKNOWLEDGEMENT}

Authors are thankful to Prof. S.P Singh, Department of Management Studies for imparting knowledge on ISM methodology which helped authors substantially while writing this piece of work.

\section{REFERENCES}

[1] Saatcioglu ,O.Y. 2007. What determines user satisfaction in ERP projects:-benefits, barriers or risks? Journal of Enterprise Information management, 22 (6), 698-708.

[2] Chang, K. , Cheung, W. , Cheng, C.H. , Yeung, J.H.Y. 2008. Understanding ERP system adoption from the user's perspective , International Journal of production economics, 113 , 928-942.

[3] Balsmeier, P., Nagar, S. 2002. Implementing ERP in India - issues and problems , Journal of Transnational Management Development, 7 (3), 3-12.

[4] Doom, C. , Milis, K. , Poelmans, S. and Bloemen, E. 2010. Critical success factors for ERP implementations in Belgian SMEs, Journal of Enterprise Information Management, 23 (3), 378-406.

[5] Elbertsen, L. and Reekum, R.V. 2008. To ERP or not to ERP? Factors influencing the adoption decision , International Journal of Management and Enterprise Development, 5, 310-330 .

[6] Kallunki, J.P., Laitinen, E.K.., Silvola, H. 2011. Impact of enterprise resource planning systems on management control systems and firm performance, International Journal of Accounting Information Systems, 12 (1), 2039 .

[7] Lee, D., Lee, S.M. , Olson, D.L., Chung , S.H. 2010. The effect of organizational support on ERP implementation, Industrial Management and Data Systems, 110 (2), 269-283.

[8] Tsai, W.H., Chen, S.P., Hwang, E.T.Y. Hsu , J.L.2010. A study of the impact of business process on the ERP system effectiveness , International Journal of Business and Management, 5 (9) , 26-37.

[9] Compeau , D.R. and Higgins , C.A. 1995. Computer selfefficacy: development of a measure and initial test MIS Quarterly, 19 (2), 189-211.
[10] Soh, C., Kien , S.S. and Tay-Yap , J. 2000. Cultural fits and misfits: is ERP a universal solution? Communications of the ACM, 43 (4) , 47-51.

[11] Basoglu, N. , Daim,T and Kerimoglu ， O. 2007. Organizational adoption of enterprise resource planning systems: a conceptual framework , Journal of High Technology Management Research, 18, 73-97 .

[12] Angeline , C. and Baral, R.R. 2015. Adoption of ERP system: An empirical study of factors influencing the usage of ERP and its impact on end user , IIMB Management Review, 27(2), 105-117.

[13] Salum, K. , Zaidi , A.M. and Zaidi , A.R. 2015. Barriers and Drivers in Cloud ERP Adoption Among SMEs , Journal of Information Systems Research and Innovation , 9(1), 9-20.

[14] Doom, C. , Milis, K., Poelmans, S. and Bloemen, E. 2010. Critical success factors for ERP implementations in Belgian SMEs , Journal of Enterprise Information Management, 23 (3) , 378-406.

[15] Venkatesh , V. 2000. Determinants of perceived ease of use: integrating control, intrinsic motivation, and emotion into the technology acceptance model, Information Systems Research, 11 (4) , 342-365

[16] Tarafdar, M. and Vaidya , S. 2006 . Challenges in the adoption of E-Commerce technologies in India: the role of organizational factors, International Journal of Information Management, 26 , 428-441.

[17] Law,C. and Ngai, E. 2007. ERP systems adoption: an exploratory study of the organizational factors and impacts of ERP success , Information and Management, 44 (4) , 418-432.L

[18] Gist ,M.E. 1987.Self-Efficacy: implications for organizational behavior and human resource management , The Academy of Management Review, 12 (3) ,472-485.

[19] Bandura , A. 1986. Social cognitive theory , Prentice Hall, Englewood Cliffs, NJ.

[20] Agarwal, R. and Karahanna, E. Time flies when you're having fun: cognitive absorption and beliefs about information technology usage, MIS Quarterly, 24 (4), 665-694

[21] Venkatesh, V. and Davis, F.D. 1996. A model of the antecedents of perceived ease of use: development and test, Decision Sciences, 27 (3) , 451-481.

[22] Venkatesh, V. and Bala , H. 2008. Technology acceptance model 3 and a research agenda on interventions, Decision Sciences, 39 (2), 273-315.

[23] Lee, D. , Lee, S.M. , Olson, D.L. and Chung, S.H. 2010. The effect of organizational support on ERP implementation, Industrial Management and Data Systems, 110 (2), 269-283.

[24] Ilin , V. Ivetic , J. and Simic , D. 2017. Understanding the determinants of e-business adoption in ERP enables firms and non-ERP enabled firms : a case study of the western Balkan Peninsula, Technology forecasting and social change , Omega , 125, 206-223.

[25] Xue, Y. , Liang, H. , Boulton, W.R. and Snyder ,C.A. 2005. ERP implementation failures in China: case studies 
with implications for ERP vendors, International Journal of Production Economics, 97 (3), 279-295.

[26] Yi, M.Y. and Davis, F.D. 2003. Developing and validating an observational learning model of computer software training and skill acquisition, Information System Research, 14 (2) , 146-169.

[27] Sokol, M. 1994. Adaptation to difficult designs: facilitating use of new technologies, Journal of Business and Psychology, 8 (3), 277-296.

[28] Karahanna, E. , Agarwal, R. and Angst, C. 2006, Reconceptualizing compatibility beliefs in technology acceptance research, MIS Quarterly, 30 (4), 781-804.

[29] Foucault, M. 1979, Discipline and punish: the birth of the prison, Peregrine Books, London .

[30] Sia, S.K. , Tang,M., Soh, C. and Boh , W.F. 2002. Enterprise resource planning (ERP) systems as a technology of power: empowerment or panoptic control? ACM Sigmis Database, 33 (1), 23-37.
[31] Elmes, M. , Strong,D. Volkoff , O. 2005. Panoptic empowerment and reflective conformity in enterprise systems-enabled organizations , Information and Organization, 15 (1) , 1-37.

[32] Warfield, J.N. 1974. Developing interconnection matrices in structural modeling. IEEE Transactions on Systems, Man, and Cybernetics, 1, 81-87.

[33] Weinrich, K.I. and Ahmad, N. 2009. Lessons learned during a decade of ERP experience: a case study International Journal of Enterprise Information Systems, 5 (1) , 55-75.

[34] Addo-Tenkorang, R. and Helo, P. 2011. Enterprise resource planning (ERP): a review literature report, Proceedings of the World Congress on Engineering and Computer Science .

[35] Kwahk, K.Y. and Kim, H.W. 2008. Managing readiness in enterprise systems-driven organizational change, Behaviour and Information Technology, 27 (1), 79-87 